\title{
Understanding walkable areas: applicability and analysis of a walkability index in a Brazilian city
}

\author{
Áreas caminháveis: aplicação e análise de um índice de \\ caminhabilidade em uma cidade brasileira
}

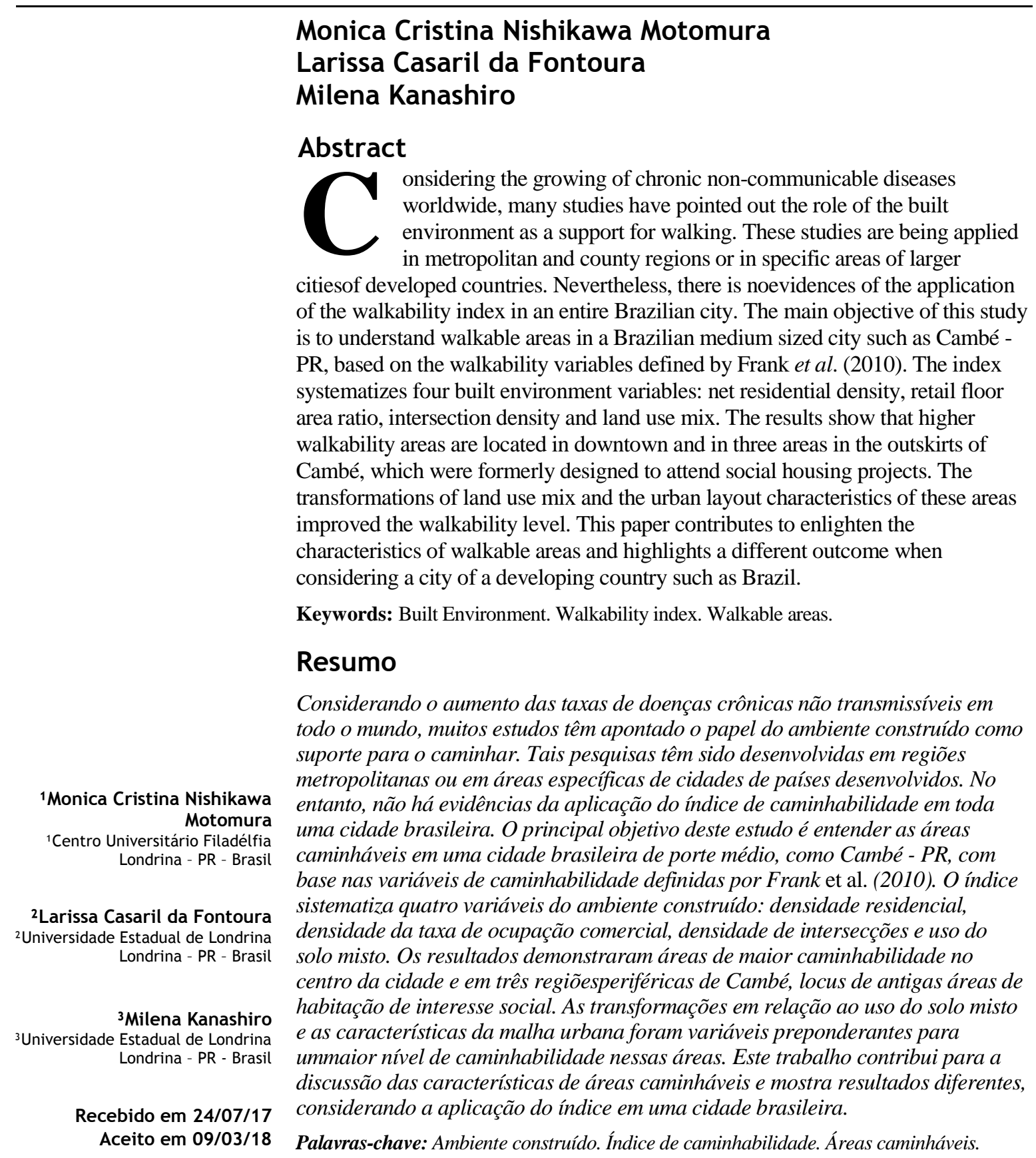

MOTOMURA, M. C. N.; FONTOURA, L. C. da; KANASHIRO, M. Understanding walkable areas: applicability and analysis 413 of a walkability index in a Brazilian city. Ambiente Construído, Porto Alegre, v. 18, n. 4, p. 413-425, out./dez. 2018. ISSN 1678-8621 Associação Nacional de Tecnologia do Ambiente Construído. http://dx.doi.org/10.1590/s1678-86212018000400313 


\section{Introduction}

Currently, studies have pointed out that our cities play an important role to support healthier lifestyles (SALLIS; BAUMAN; PRATT, 1998; HUMPEL et al., 2002; DING; GEBEL, 2012). This approach emerges considering the increase of physical inactivity rates worldwide (BROWNSON et al., 2009; NG; POPKIN, 2012). Researches show that non-communicable diseases (NCDs) such as cardiovascular diseases, hypertension, diabetes (type 2) and some types of cancers, are preventable through regular physical activity, which has also been related to improved wellbeing (BERKE et al., 2007). NCDs were the causes of $74 \%$ of death in 2014 (WORLD..., 2014), and this scenario is repeated mainly in lowincome population.

One of the strategies to evaluate the built environment for supporting a more active daily life is the so-called walkability index, that has been applied worldwide. Its application is based on using reduction tools such as the factor analysis, which is a statistical process that examines the built environment's components to define a smaller set of basic common dimensions. Many walkability indexes have been applied (FRANK et al., 2006; OWEN et al., 2007; SALLIS et al., 2009; LOTFI;KOOHSARI, 2011; REIS et al., 2013; CAUWENBERG et al., 2016) (Figure 1). However, the index systematized by Frank et al. (2006), and sharpened in 2010, concerning four variables of the built environment (land use mix, street connectivity, net residential density and retail floor area ratio) is the most widespread and applied one. According to Frank et al. (2010), this index can contribute to survey design purposes and enlighten travel choice and physical activity.

Frank et al. (2010) index defines four variables: (a) Net Residential Density (the ratio of residential units to the land area established for residential use);

(b) Retail Floor Area Ratio (the retail building floor area footprint divided by the retail land floor area footprint);

(c) Intersection Density (related to the connectivity of the street network, considering the ratio of the number of true intersections in the area); and

(d) Land Use Mix (related to the diversity of the land use types in a block group classified in: residential, retail (excluding "big boxes"), entertainment (including restaurants), office and institutional (including schools and community institutions).

The walkability index is calculated by the following formula: $[(2 \mathrm{x} \quad \mathrm{z}$-score intersection density $)+(z$-score net residential density $)+(z-$ score retail floor area ratio $)+(z$-score land use mix)], and all variables are normalized by the " $\mathrm{Z}$ score" (FRANK et al., 2010).

Walkability indexeswere applied in cities of developed countries: in metropolitan regionsin Australia (MAYNE et al., 2013) and in county regions in the United States (FRANK et al., 2010). In Latin America, walkability indexes were applied in larger cities such as Curitiba - Brazil (REIS et al., 2013), considering only selected census tracts of the city, and in Bogotá, Cervero et al. (2009) considered walkability index variables to examine walking in the neighborhood scale. Therefore, these indexes and studies are being applied to analyze walkability in major areas (metropolitan or county regions) or selected city sectors (neighborhoods or census tracts) but no evidence of the application of the walkability index in an entire Brazilian city was found. 
Figure 1 - Variables of Walkability Indexes

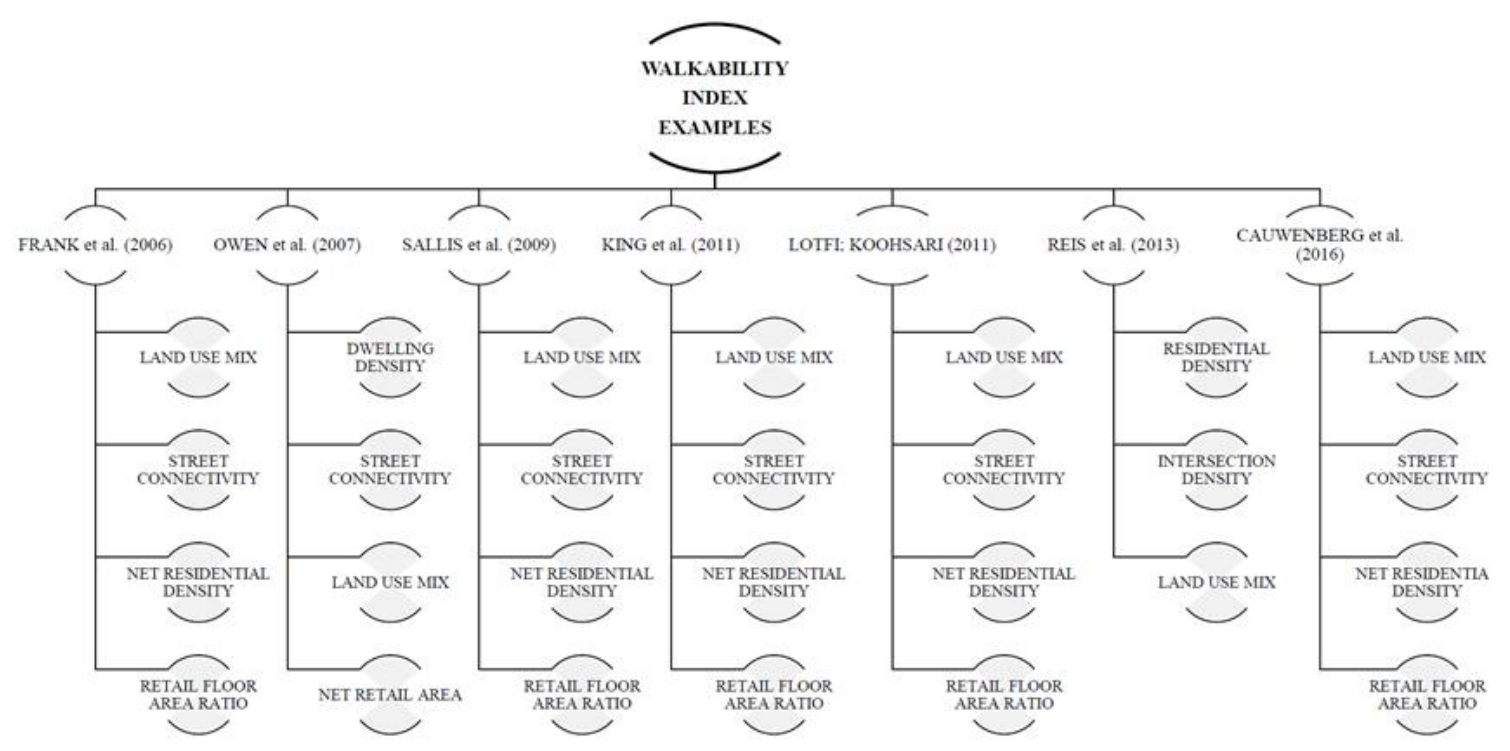

Therefore, the main objective of this study is to understand walkable areas in a Brazilian medium sized city. The application of the walkability index developed by Frank et al. (2010) in a whole Brazilian city can enlighten if the walkability index is suitable for our built environment characteristics along with the data collection process. The majority of Brazilian cities are smaller and present an average between 5 to 100 thousand inhabitants (INSTITUTO..., 2015). Considering that the smaller the city, the higher the rates of walking for travel purposes (ASSOCIAÇÃO..., 2018), walkability researches are significant to be applied in Brazil, especially where non-motorized transportation is more intense.

According to Frank et al. (2010), understanding walkability can lead to a greater understanding in the health field and in the sphere of impacts of transport investments and decisions over land use involving the built environment and quality of life. Environmental studies related to walking are necessary in low-income and middle-income countries (BAUMAN et al., 2012) in order to mitigate physical inactivity caused by the increase of motorized transport use, urbanization and passive leisure activities. These issues give an opportunity to investigate the built environment associated with walking to reduce sedentary behaviors (REIS et al., 2013).

This contribution could enable us to comprehend the multiple urban arrangement components aiming at achieving active mobility and to contribute to understand the characteristics of the built environment for supporting physical activity in Brazilian cities.

\section{Methodology}

The methodological strategy adopted was the Case Study, and according to Yin (2001) this approach can be used when it is necessary to deal with contextual issues that are required to understand a phenomenon of study. This strategy is applicable to answer "why" and "how" questionings (YIN, 2001) and, for this study, it was necessary to comprehend why some areas present higher walkability and how walkability variables can contribute to this outcome. Firstly, a single case study for collecting and analyzing empirical evidence of walkability index variables in Cambé is presented, and secondly, multiple cases studies in order to compare the most walkable areas in Cambé for descriptive and explanatory outcomes.

The case study considered is the city of Cambé, located in the North of Paraná State. It has 494,692 $\mathrm{km}^{2}$ and had an estimated population of 103.822 in 2015 (INSTITUTO..., 2015). Its economy is focused on soy agriculture and the town has a significant industrial complex including mostly agribusiness and chemical industries.

The first data collection approach is the geographical boundaries for systematizing the walkability surface variables. Frank et al. (2010) and many others indexes applied the walkability index based on census tracts. This strategy facilitates further correlations between walkability and sociodemographic issues, e.g. income, schooling, gender, age.

For the construction of the walkability index, firstly a map of the census tracts was organized according to the Brazilian Institute of Geography 
and Statistics (IBGE), which are the basis for setting up the index (Figure 2).

Considering the census tracts in Cambé - PR, digital maps were made on AutoCAD 2015 and on ArcGIS 10.4 Free Version, and Excel 2013 was used for setting the data. According to the index variables, some criteria of data collection were defined in order to systematize the variables to format the walkability index for Cambé (Table 1). Each variable was mapped - intersection density, land use mix, residential density and retail floor area ratio - for the calculation of the walkability index (Figure 3).

\section{Results}

A map of the walkability index in Cambé was systematized and it demonstrated the distribution of walkability classifications among the census tracts. Considering the scale of the town, the tertile classification was adopted. The walkability index map demonstrates three classes of walkability and the tertile distribution comprises 28 (twenty-eight) census tracts for each class: the main two edges (higher and lower walkability) and the transition between them (medium walkability) (Figure 4).

Analyzing the walkability index map of Cambé, a concentric structure can be observed: areas with higher walkability are followed by areas of medium and, finally, by lower walkability areas. Thus, census tracts with lower walkability rates are located in the peripheral areas, which present a more recent urbanization process and are mainly for lower density residential areas (e.g. census tract 80 ) or are characterized by industrial use (census tracts $10,13,22,59,74$ and 75).

These areas are characterized as urban voids without continuity of the urban layout. On the other hand, most of the higher walkability areas are situated within census tracts' clusters in the downtown area (census tracts 2 and 3 ) and in three areas in the outskirts of the city. These spatial characteristics, in the first approach, seem to be closely related to the process of the urban development of Cambé, which should be understood before examining walkable areas.

\section{Figure 2 - Census tracts of Cambé - PR considered for the study}

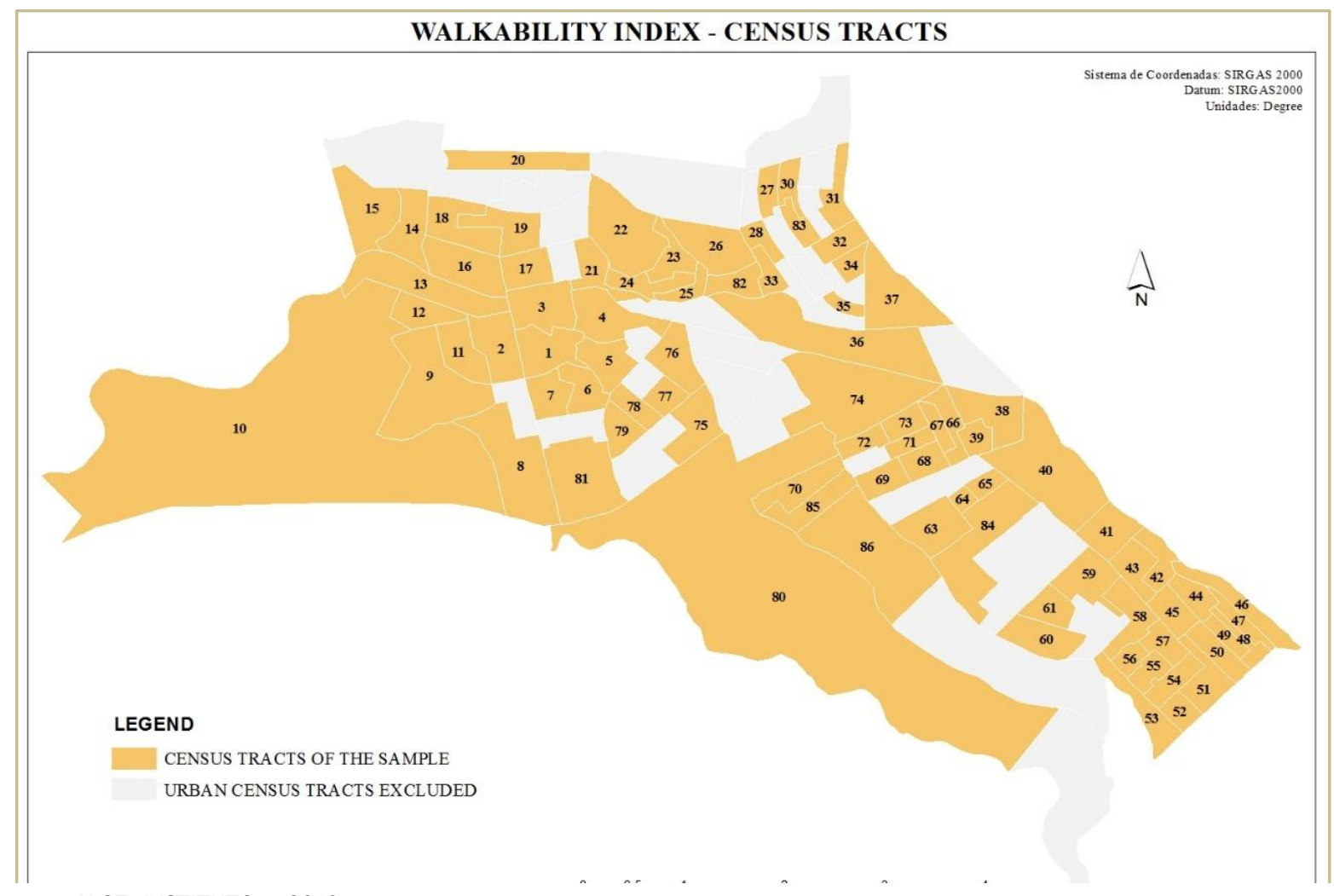

Source: IBGE (INSTITUTO..., 2010). 
Table 1 - Criteria adopted for each variable of the walkability index

\begin{tabular}{|l|l|}
\hline \multicolumn{1}{|c|}{ VARIABLE } & \multicolumn{1}{|c|}{ CRITERIA FOR THE CONSTRUCTION OF THE WALKABILITY } \\
INDEX
\end{tabular}

\section{Figure 3 - Base maps for the calculation of the walkability index}

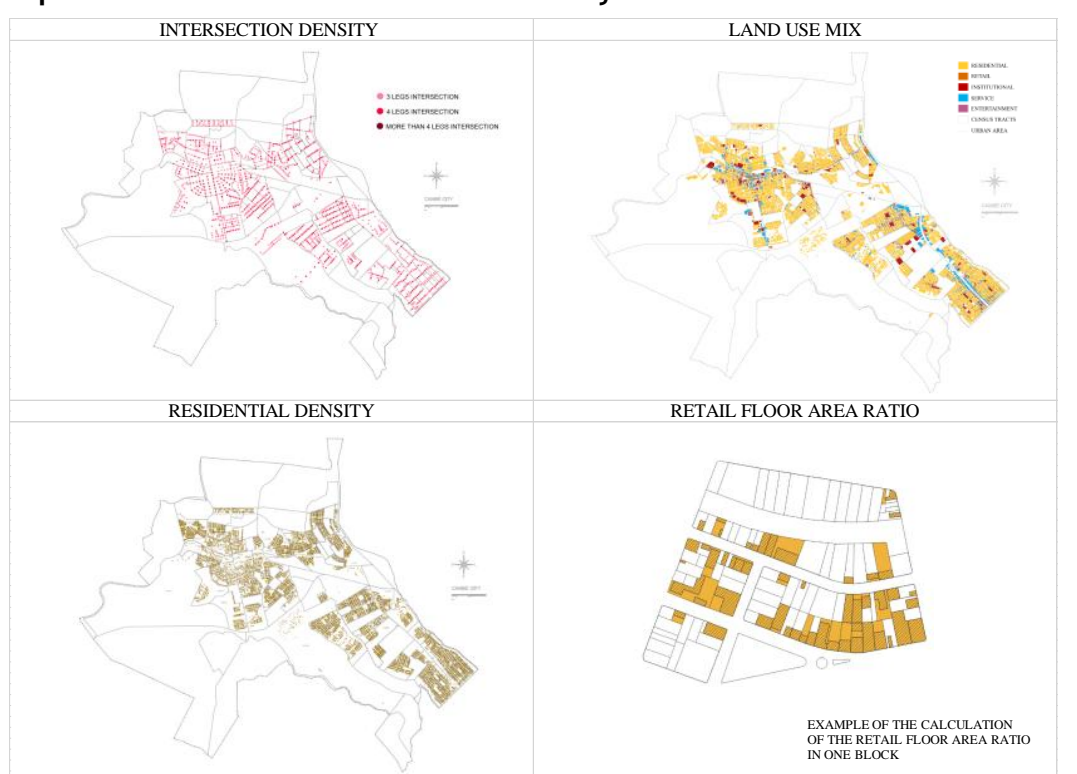

Source: Cambé Townhall (2015), Instituto Brasileiro de Geografia e Estatística (2010) and Google Maps (2016). 
Figure 4 - Walkability Index Map

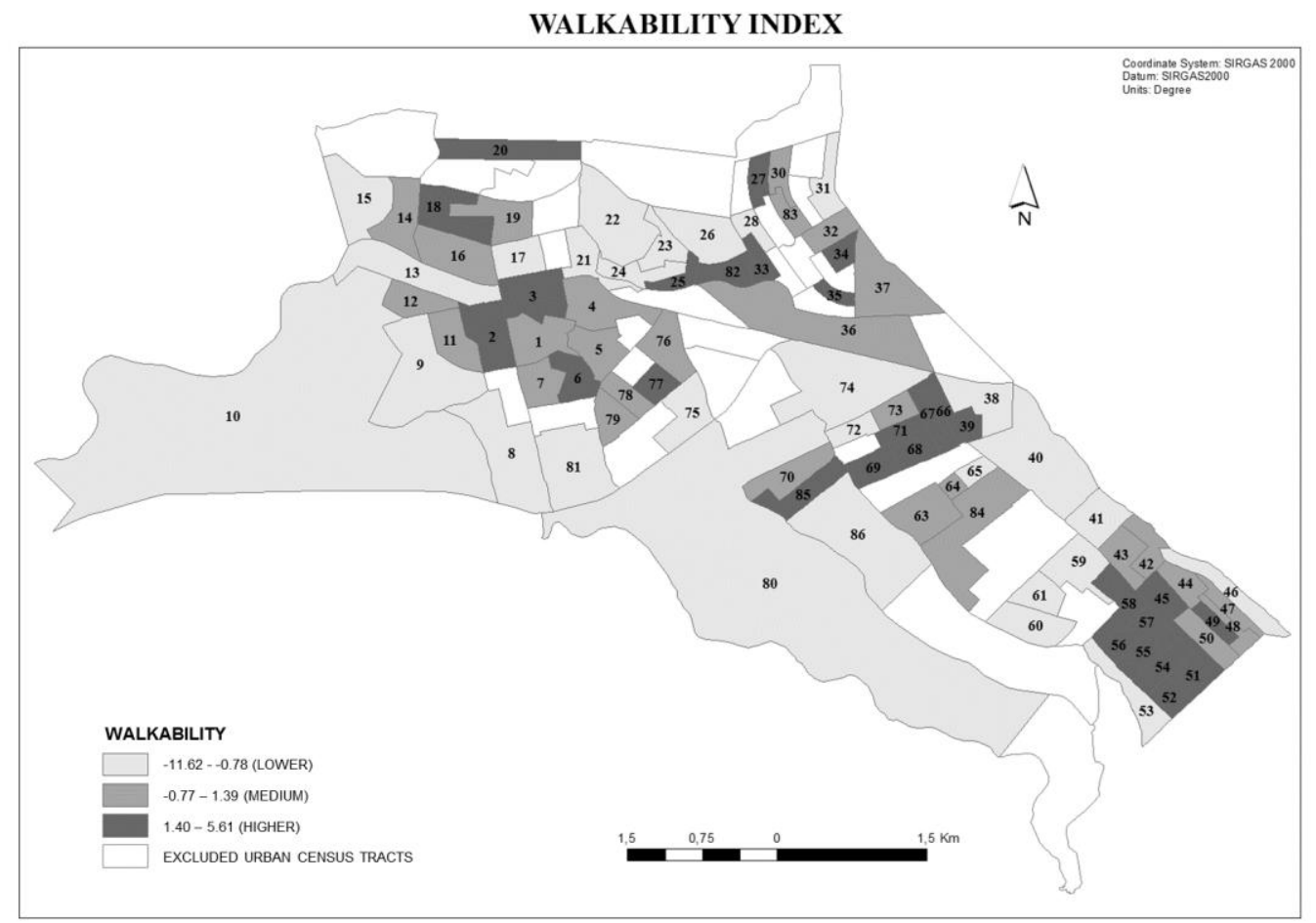

\section{Walkability index outcomes and the historical process in Cambé - PR}

Cambé can be considered a new town, since it was implemented in 1932 as part of the CTNP (Companhia de Terras Norte do Paraná), a subsidiary of Paraná Plantations Ltd Company, established in London, England. The CTNP was responsible for the colonization process of the Northern Paraná region, where 63 cities were planned in a network of hierarchical urban centers, connected with a system of roads and railways (YAMAKI, 2003). The railway was a fundamental element for the colonization process since its construction and was the element that attracted the creation and implementation of new cities in the North of Paraná. In addition, it was also the structuring element which determined where cities would be situated, marking the landscape (REGO, 2009). The rural land subdivisions provided by the CTNP were based on small rural lots (YAMAKI, 2003; REGO, 2009), which surrounded the urban centers aiming the interests of the small producer, who at that time, cultivated mainly coffee (REGO, 2009).

The initial core of Cambé is composed of a semicircle in the south side of the railway. Because of the urban migration, two new urban cores emerged in addition to the existing central core. Those new areas were developed both during the same period and far from the initial core, and were not only developed for the industry, but also for providing social housing. This resulted in a scattered structure that emphasizes the Brazilian urban segregation of the lower social class (Figure 5).

The original core is the downtown area where there is a prevalence of retail and services, and therefore constitutes the main economical exchange place. Until the 1950s, the growth of Cambé occurred around the original core, with the incremental growth of new areas. After the 1960s, scattered development started to appear along highway BR-369, which served as a connector axis after the establishment of the other two cores of social housing projects: Industrial and Bandeirantes (Figure 6). The Industrial Core was created to attend the housing demand of the working-class and resulted in small sized lots arrangements, which, according to Brazilian regulations, strengthened the formation of dense districts. On the other hand, the Bandeirantes Core, once was situated far from downtown and closer to the city of Londrina, presented an economical dependency with the latter (SILVEIRA, 1989). The three main urban cores play an important role in Cambé, each one with its specific spatial characteristics related to the historical process. According to the morphogenetic

418 Motomura, M. C. N.; Fontoura, L. C.da; Kanashiro, M. 
concept, distinct fragments of cities represent different temporalities and identities, resulting in a diverse arrangement of spaces (KRAFTA, 2014).

The analyses of the walkability index map show that census tracts' clusters with higher walkability are typically concentrated in these three cores (original, industrial and Bandeirantes). Another small cluster was formed by three adjacent higher walkability census tracts $-25,33$ e 82 - that are situated along the access to Cambé from PR-445 highway. Physical barriers, such as the railway, the highways and the valleys divide Cambé, and have therefore, strengthened the formation of the clusters (Figure 7).

Figure 5 - Urban cores in Cambé - PR

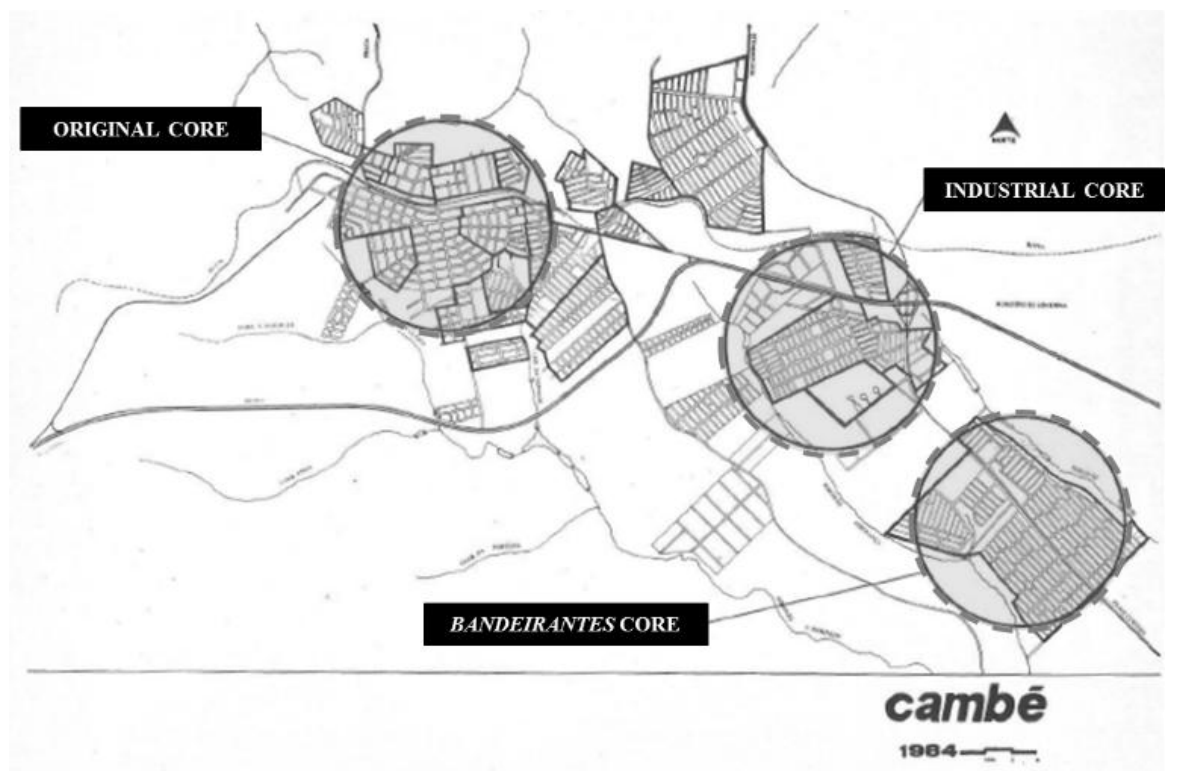

Source: Silveira (1989).

Figure 6 - Cambé - PR urbangrowth

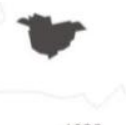

1930
151,8 ha

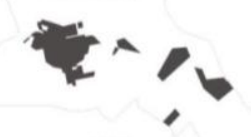

1960
461,9 he
$\operatorname{cresc} 177 \%$

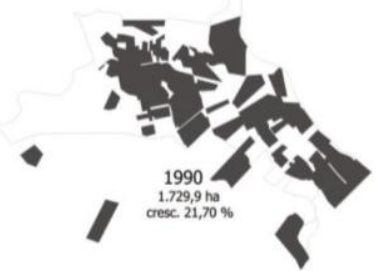

Source: Cambé (2008 ${ }^{1}$ apud CAMBÉ, 2012).

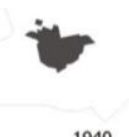

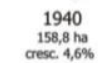
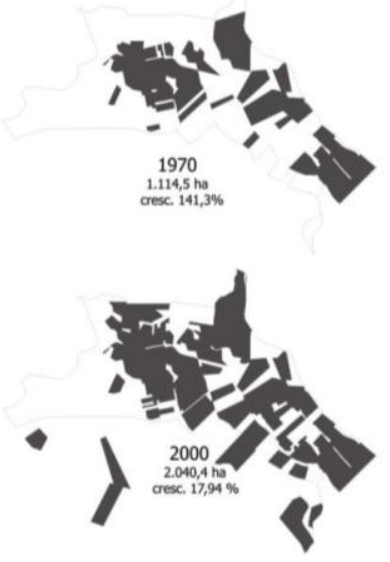

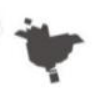

1950
$166,9 \mathrm{ha}$
cesc. $5,11 \%$

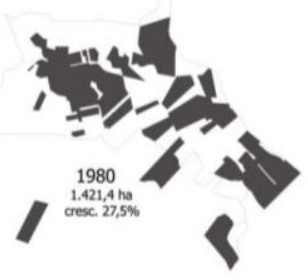

${ }^{1}$ CAMBÉ. Secretaria Municipal de Administração. Plano Diretor de Cambé. Cambé, 2008. 


\section{Higher walkability clusters in Cambé - PR}

A detailed analysis of each high walkability cluster pointed out their spatial arrangements considering the four variables of the index. The Original Core cluster (downtown) is outlined by census tracts 2 and 3 (Figure 8). It can be verified that land use mix and the density of street intersections prevail, confirming that both of them contribute to a higher walkability. The central area of Cambé presents different types of use, including residential use. This mix of uses enhances accessibility as Saelens; Sallis; Frank (2003) pointed out in their study. However, the greatest land use mix includes mainly retail, service and institutional uses that take place along the two main roads: Inglaterra and Brasil Avenues.Even though the former area is characterized by large block format (square shape with $80 \mathrm{~m} \times 150 \mathrm{~m}$ ), there is a continuity of the urban tissue, increasing the intersection density, and also a higher residential density.

The other three clusters in the outskirts of the city are located in areas that historically were settled for social housing projects: Industrial, Bandeirantes and Ana Rosa cores (Figure 9). The pattern for social housing projects in Brazil is usually characterized by a grid with rectangular blocks without retail areas. This typology is a strategy to respond to the housing shortage, by providing a higher number of houses within a smaller lot. Therefore, because they present an orthogonal grid, usually $50 \mathrm{~m} \times 100 \mathrm{~m}$, these areas are well connected with a higher intersection density and are more compact.

In the case of Industrial and Bandeirantes cores, due to the distance from the city center and to be segregated by the highway and railway, these areas with a higher residential density gradually improved their retail areas. Withinthis phenomenon is it feasible to observe where the main streets provide access to the residential areas and they show a concentration of retail and services uses, unfolding in a linear mixed-use pattern. Although, there is still a prevalence of residential use, the clusters are well supplied by many types of land use. In areas with higher residential density, services arise for attending the demand and, according to Beaujeu-Garnier (1997), retail business have the tendency to be implemented in the most central area in order to take full advantage of the communication networks.

Figure 7 - Clusters defined by higher walkability census tracts in Cambé

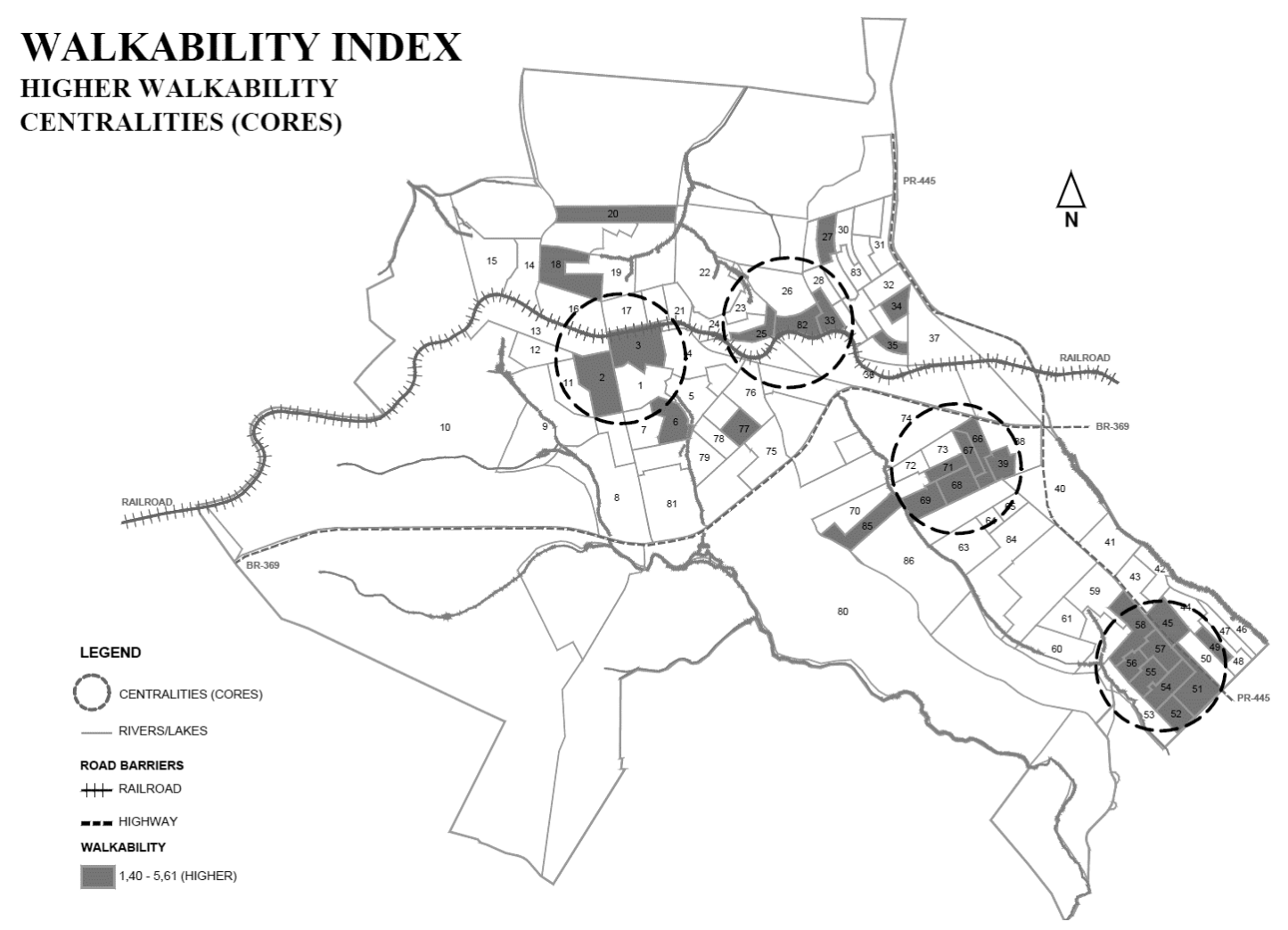

Source: Cambé Townhall (2015) and IBGE (INSTITUTO..., 2010). 
Figure 8 - Original core cluster: land use mix and street intersections

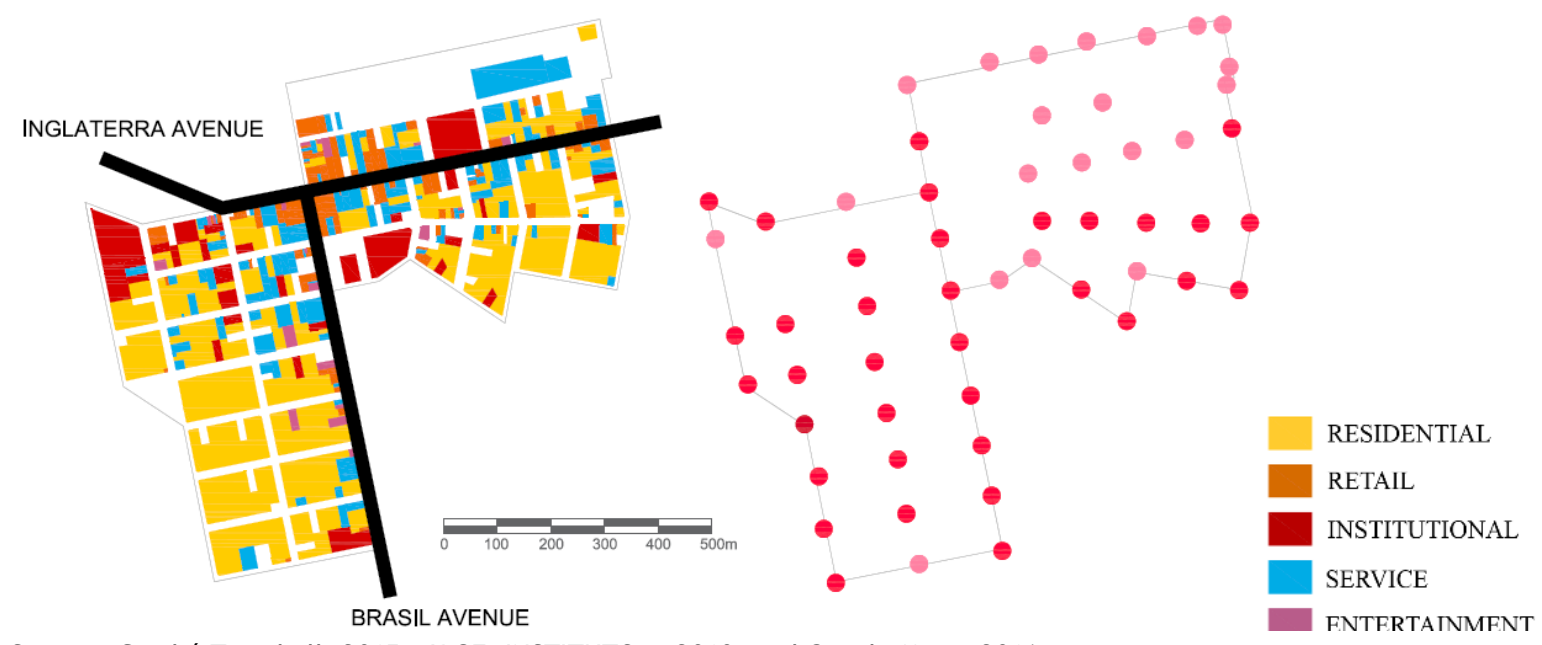

Source: Cambé Townhall (2015), IBGE (INSTITUTO..., 2010) and Google Maps (2016).

Figure 9 - Outskirts clusters: land use mix and street intersections

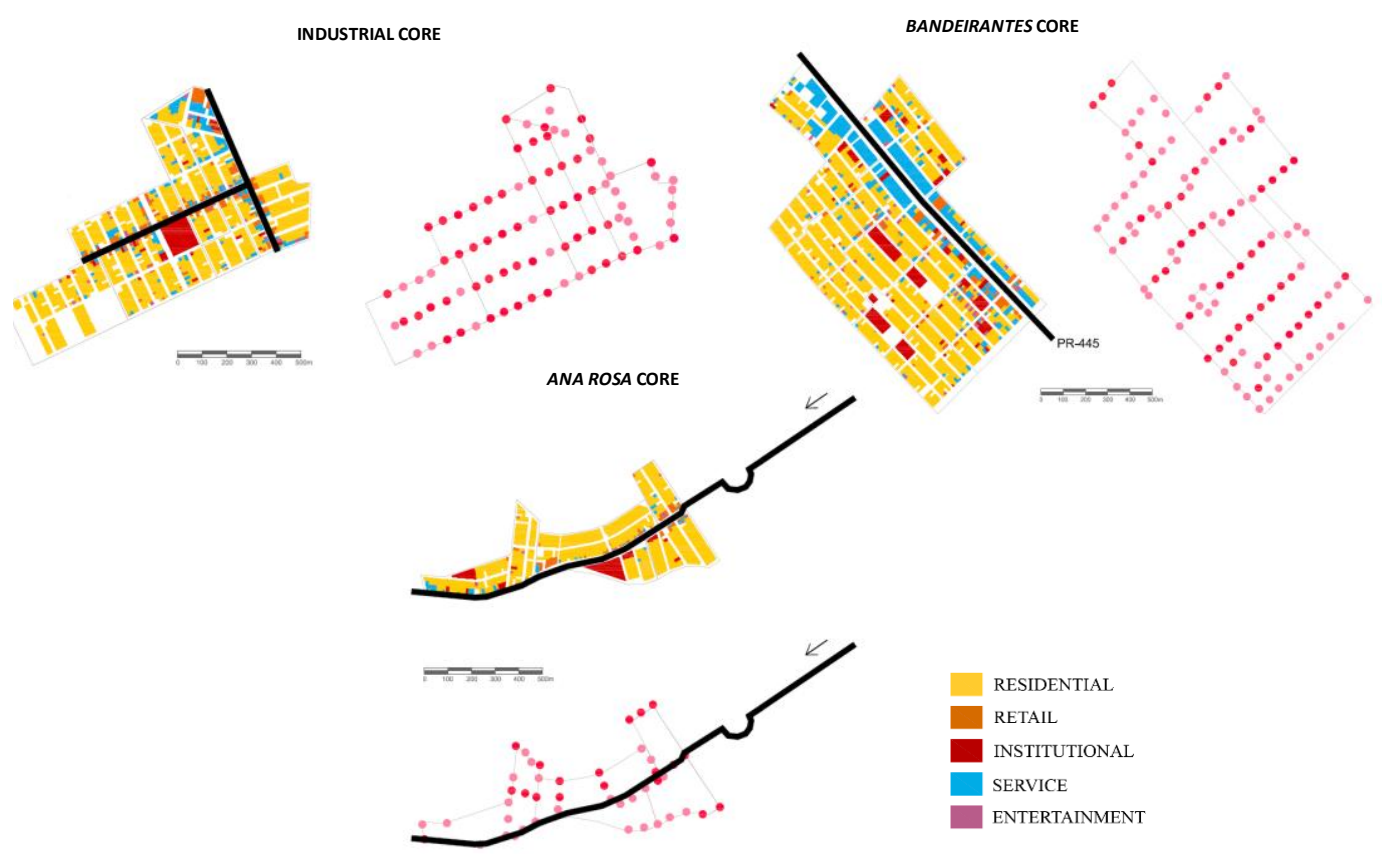

Source: Cambé Townhall (2015), IBGE (INSTITUTO..., 2010) and Google Maps (2016). 
Figure 10 - Census Tracts and Spatial Diversity

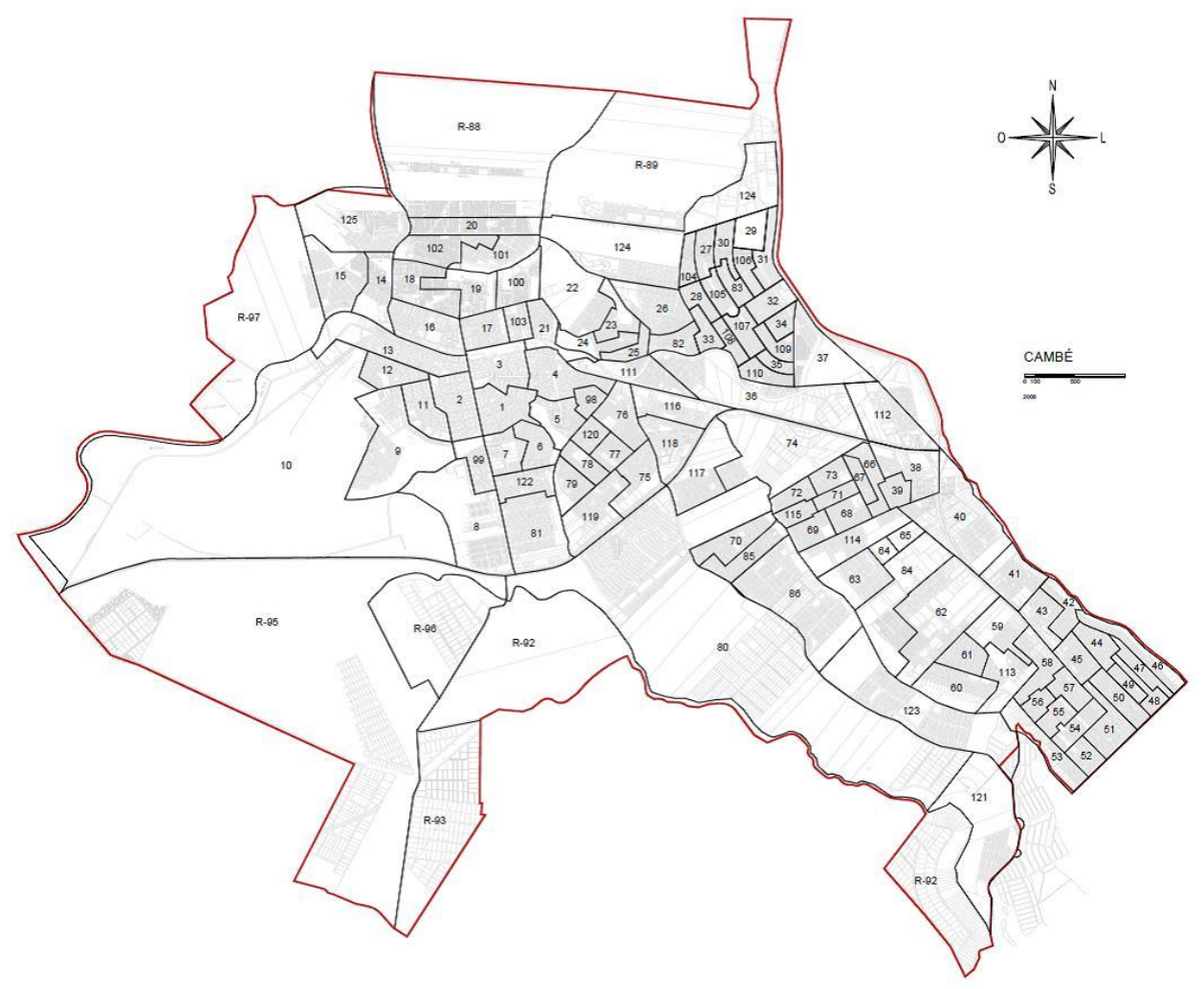

Source: IBGE (INSTITUTO..., 2010).

\section{Conclusion}

The important challenge that this research undertook was the application of a walkability index in an entire city such as Cambé - PR. Firstly, during the data collection process, it was necessary to define conditions to calculate the land use mix, which was not pointed out for others countries. In Brazilian cities, there is a significant presence of different land uses in the same lot, considering two basic typologies: isolated or in the same building. This characteristic could have affected the data collection if the conditions were not well established.

Secondly, applying the walkability index in Cambé in the whole city showed some different walkability outcomes in comparison with the walkability indexes that were applied before. The results from the spatial analysis point out that the walkability index variables are distributed according to the conformation of physical barriers such as highways and railroad and that isolated areas might become new centralities with higher land use mix and higher intersection density. The sedimentation of these new centralities showed the relation between walkable census tracts and former urban sectors of Cambé, and these areas transformed previous residential lots in retail, improving the accessibility to daily needs.

The former social housing projects and the downtown areas in Cambé were consideredwalkable areas. Although, they are areas characterized by greater land use mix, where the propensity for walking for transportation is greater (FRANK et al., 2012), it is necessary to point out a limitation of the land use mix definition for the index, which is the entropy calculation. The entropy formula measures how variable is the land use mix numerically and only considers the proportion between different uses. For example, if there are $30 \%$ of residential use and $70 \%$ of retail use, the numerical result will be the same if considered $70 \%$ of residential use and $30 \%$ of retail use. This calculation does not take into account the importance, interactions or even configuration between land uses (HESS; MOUDON; LOGSDON, 2001; MANAUGH; KREIDER, 2013).

The analysis of the walkability index applied worldwide used the census tracts as the geographical scale. Although these areas may be homogeneous considering socioeconomic issues, they are heterogeneous when considering others environmental characteristics. In Brazil, according to IBGE, census tract is established as a

422 Motomura, M. C. N.; Fontoura, L. C.da; Kanashiro, M. 
contiguous area, concerning administrative unit and parameters for data collection (Figure10). The heterogeneity of the urban tissue in census tracts was observed and this could affect negatively the use of reduction tools to measure the built environment characteristics for the walkability index. Therefore, there is a challenge to establish homogeneous spatial patterns that better aggregate the walkability variables.

There is a significant amount of literature from all over the world discussing the relationships between urban form and travel characteristics, showing that the urban form can influence travel patterns and its environmental impacts (STEAD; MARSHALL, 2001). However, it is necessary to consider more discussions about how the variables of the walkability index (FRANK et al., 2010) can influence human behavior. The urban form and its qualitative approach can give supportive insights about how cities can contribute to positive human behaviors outcomes, including walking as a strategy to promote physical activity in daily life of people.

\section{References}

ASSOCIAÇÃO NACIONAL DE TRANSPORTES PÚBLICOS. Urban Mobility Information System General Report 2011, 2012. Available in:

<http://www.antp.org.br/_5dotSystem/download/d cmDocument/2013/04/11/050FC84C-74EA-4A33A919-6D2E380FA2C1.pdf>. Access: 11 Jul. 2018.

BAUMAN, A.et al. Correlates of Physical Activity: why are some people physically active and others not? The Lancet, v. 380, n. 9838, p. 258-271, 2012.

BEAUJEU-GARNIER, J. Geografia Urbana. 4. ed. Lisboa: Fundação Calouste Gulbenkian, 1997.

BERKE, E. et al. Association of the Built Environment With Physical Activity and Obesity in Older Persons. Research and Practice, v. 97, n. 3, p. 486-492, mar. 2007.

BROWNSON, R. et al. Measuring the Built Environment for Physical Activity. State of the Science. American Journal of Preventive Medicine, v. 36, n. 4S, p. S99-S123, 2009.

CAMBÉ. Plano Municipal de Habitação de Interesse Social - Cambé-PR: diagnóstico habitacional. Cambé: Ministério das Cidades/FAUEL, 2012.

CAMBÉ Townhall. Digital Documents, 2015.
CARMONA, M. et al. Public Places Urban Spaces: the dimension of urban design. $2^{\text {nd }}$. ed. Oxford: Elsevier, 2010.

CAUWENBERG, J. et al. Neighborhood Walkability and Health Outcomes Among Older Adults: the mediating role of physical activity. Health \& Place, v. 37, p. 16-25, 2016.

CERVERO, R. et al. Influences of Built Environments on Walking and Cycling: lessons from Bogotá. International Journal of Sustainable Transportation, v. 3, p. 203-226, 2009.

DING, D.; GEBEL, K. Built Environment, Physical Activity, and Obesity: what have we learned from reviewing the literature? Health \& Place, v. 18, n. 1, p. 100-105, 2012.

ELLIS, G. et al. Connectivity and Physical Activity: using footpath networks to measure the walkability of built environments. Environment and Planning B: Planning and Design, v. 42, p. 1-22, 2015.

FRANK, L. et al. Many Pathways From Land Use to Health. Journal of the American Planning Association, Chicago, v. 72, n. 1, p. 75-87, 2006.

FRANK, L. et al. The development of a walkability index: application to the Neighborhood Quality of Life Study. British journal of sports medicine, v. 44, n. 13, p. 924-933, 2010.

FRANK, L. et al. Health and the Built Environment: a review. The Canadian Medical Association, 2012.

GOOGLE MAPS. [Map]. Available in: <https://www.google.com.br/maps>. Access in: 10 apr. 2016.

HESS, P.; MOUDON, A.; LOGSDON, M. Measuring Land Use Patterns For Transportation Research. Transportation Research Record: Journal of the Transportation Research Board, v. 1780, p. 17-24, 2001.

HUMPEL, N. et al. Environmental Factors Associated With Adults' Participation in Physical Activity: a review. American Journal of Preventive Medicine, v. 22, n. 3, p. 188-199, 2002.

INSTITUTO BRASILEIRO DE GEOGRAFIA E ESTATÍSTICA.Censo Demográfico 2010. Rio de Janeiro: IBGE, 2010.

INSTITUTO BRASILEIRO DE GEOGRAFIA E ESTATÍSTICA. Estimativas Populacionais dos Municípios em 2015. Available in: <http://saladeimprensa.ibge.gov.br/noticias?view= noticia\&id=1\&busca=1\&idnoticia=2972>. Access 11 jul. 2018. 
JACOBS, J. Morte e Vida de Grandes Cidades. 3. ed. São Paulo: Martins Fontes, 2011.

KRAFTA, R. Notas de Aula de Morfologia Urbana. 1. ed. Porto Alegre: Editora da UFRGS, 2014.

LOTFI, S.; KOOHSARI, M. Neighborhood Walkability in a City within a Developing Country. Journal of urban planning and development, v. 137, p. 402-408, Dec. 2011.

MANAUGH, K.; KREIDER, T. What is Mixed Use? Presenting an interaction method for measuring land use mix. Journal of Transport and Land Use, v. 6, n. 1, p. 63-72, 2013.

MAYNE, D. J. et al. An Objective Index of Walkability For Research and Planning in the Sydney Metropolitan Region of New South Wales, Australia: an ecological study. International journal of health geographics, v. 12, p. 61, 2013.

NG, S.; POPKIN, B. Time Use and Physical Activity: a shift away from movement across the globe. Obesity Reviews, v. 13, n. 8, p. 659-680, 2012.

OWEN, N. et al. Neighborhood Walkability and the Walking Behavior of Australian Adults. American JournalofPreventive Medicine, v. 33, n. 5, p. 387-395, 2007.

REGO, R. L. As Cidades Plantadas: os britânicos e a construção da paisagem do norte do Paraná. Maringá: Edições Humanidades, 2009.

REIS, R. et al. Walkability and Physical actiVity: findings from Curitiba, Brazil. American Journal of Preventive Medicine, v. 45, n. 3, p. 269-275, 2013.

SAELENS, B.; SALLIS, J.; FRANK, L.

Environmental Correlates of Walking and Cycling: findings from the transportation, urban design, and planning literatures. Annals of behavioral medicine : a publication of the Society of Behavioral Medicine, v. 25, n. 2, p. 80-91, 2003.
SALLIS, J. et al. Neighborhood Built Environment and Income: examining multiple health outcomes. Social Science and Medicine, v. 68, n. 7, p. 12851293, 2009.

SALLIS, J.; BAUMAN, A.; PRATT, M.

Environmental and Policy Interventions to Promote Physical Activity. American journal of preventive medicine, v. 15, n. 4, p. 379-397, 1998.

SILVEIRA, R. Planejamento Urbano

Participativo: a experiência de Cambé. Londrina: Universidade Estadual de Londrina, 1989.

STEAD, D.; MARSHALL, S. The Relationships Between Urban Form and Travel Patterns: an international review and evaluation. European Journal of Transport and Infrastructure Research, v. 1, n. 2, p. 113-141, 2001.

SOUTHWORTH, M. Designing the Walkable City. Journal of Urban Planning and Development, v. 131, n. 4, p. 246-257, dec. 2005.

SUNG, H. et al. Land Use Policy Effects of StreetLevel Physical Environment and Zoning on Walking Activity in Seoul, Korea. Land Use Policy, v. 49, p. 152-160, 2015.

WORLD ECONOMIC SITUATION AND PROSPECTS. World Economic Situation and Prospects Report, 2014.

WORLD HEALTH ORGANIZATION. Non Communicable Diseases Country Profiles.2014.

YAMAKI, H. Iconografia Londrinense. Londrina: Edições Humanidades, 2003.

YIN, R. Estudo de Caso: planejamento e métodos. 2. ed. Porto Alegre: Bookman, 2001.

\section{Agradecimentos}

À Capes, pela bolsa concedida para a realização do mestrado PPU/UEL-UEM, e ao financiamento da pesquisa pela Fundação Araucária (Edital PBA/2016). Agradecemos aos componentes do grupo de Pesquisa Design Ambiental Urbano e a contribuição dos avaliadores. 
Monica Cristina Nishikawa Motomura

Departamento de Arquitetura e Urbanismo | Centro Universitário Filadélfia | Av. Juscelino Kubitschek, 1626 | Londrina - PR - Brasil | CEP 86020-000 | Tel.: (43) 3375-7447 | E-mail: monicamotomura@gmail.com

\section{Larissa Casaril da Fontoura}

Departamento de Arquitetura e Urbanismo | Universidade Estadual de Londrina | Rodovia Celso Garcia Cid, PR 445 Km 380 | Caixa Postal 10.011 | Londrina - PR - Brasil | CEP 86057-970 | Tel.: (43) 3371-4535 | E-mail: larissadafontoura@gmail.com

\section{Milena Kanashiro}

Departamento de Arquitetura e Urbanismo | Universidade Estadual de Londrina | E-mail: milena@uel.br

\section{Revista Ambiente Construído}

Associação Nacional de Tecnologia do Ambiente Construído

Av. Osvaldo Aranha, $99-3^{\circ}$ andar, Centro

Porto Alegre - RS - Brasil

$$
\text { CEP } 90035-190
$$

Telefone: +55 (51) 3308-4084

Fax: +55 (51) 3308-4054

www.seer.ufrgs.br/ambienteconstruido

E-mail: ambienteconstruido@ufrgs.br

This is an open-access article distributed under the terms of the Creative Commons Attribution License. 